\title{
M-Commerce in Bangladesh -Status, Potential and Constraints
}

\author{
Biman Barua \\ Senior Lecturer, Department of AMT, \\ BGMEA University of Fashion and Technology, Dhaka -1230, Bangladesh \\ Email: biman@buft.edu.bd
}

\begin{abstract}
Mobile Commerce often referred to as "MCommerce" or "mCommerce" is a new dimension or extension of e-Commerce that is performed by mobile devices and Personal Digital Assistants (PDA) using mobile phone networks. As the number of mobile users is increasing dramatically the prospect of m-commerce is also increasing day by day in developing countries like Bangladesh. Though there are a lot of researchers has written about the prospect and adoption of M-commerce but in my research, I tried to find out the statistical analysis of mobile users, mobile internet users; Mcommerce current status in Bangladesh. Research also has been done for a number of visitors of stakeholder's site, using the ranking tools, uses of mobile apps by customers and limitation of mobile commerce adoption in Bangladesh those were not discussed earlier. Here, I collected data through web and phone call from various stakeholders, in the top line m-commerce business, studied and identified the problem, shown the current status and major barriers of M-commerce and suggested a methodological framework.
\end{abstract}

Index Terms-M-Commerce, Barriers, Mobile Commerce, Mobile operators, Bangladesh.

\section{INTRODUCTION}

The expansion of the technology and revolution of mobile communication in the rural area of Bangladesh it has eventually been a motivating variable in the development of M-Commerce. In the present Business organizations, mobile commerce has been presented to account, administration, retail, and telecommunication and data innovation administrations. In these areas, MCommerce is not just being broadly acknowledged additionally it is by and large more utilized as a wellknown method for business/commerce. In this paper, I attempt to give an outline of the essentials about mcommerce present statistics and limitations.

M-commerce is on a development track. It is increasing expanding acknowledgment amongst the various areas of Bangladesh. This development can be followed back to innovating and demographical advancements that have affected vital parts of the socioeconomic condition in today's reality. The requirement for adaptability is by all accounts an essential main motivation behind M-Commerce applications, for example, Mobile Entertainment, Mobile Banking and Mobile Marketing.

In Bangladesh, there is an amazingly developing number in the reception of wireless technologies in the range of $\mathrm{M}$-commerce as there are more purchasers have a cell phone than having a PC at home. This is again clear in the figures reported by the Ministry of Finance, Bangladesh that currently the quantity of mobile users in Bangladesh is increasing rapidly. Notwithstanding, Mcommerce is still generally new wonder contrasted with different markets in Europe and in Asia Pacific to be specific Japan, Hong Kong, Taiwan, and Singapore. The greater part of the organization in Bangladesh is still slow in giving M-commerce administrations because of lack of timely and reliable systems for the delivery of physical goods, low bank account and credit card penetration, low income, and low computer and the low rate of internet users in Bangladesh.

The main objective of the research are to discover the current statistics of m-commerce, future prospects and the main barriers on M-Commerce adoption in Bangladesh. Also suggested some recommendations to implement $\mathrm{M}$ Commerce successfully in Bangladesh.

The research also considers the opportunity for online payment methods and delivery systems that would enable it to help more mechanisms of the business transaction process in a developing country such as Bangladesh.

\section{LITERATURE REVIEW}

\section{A. M-Commerce History and Current Statistics}

The rapid growth of the mobile phone users and mobile applications over the year mobile has become a vital part of human life. With the rise of mobile user, mobile commerce gets the highest priority to do business using it.

The use of mobile technology as a payment gateway was started in 1997 when Coca-Cola introduced the initial two cell telephone empowered candy machines in Finland. They could send portable installments to the candy machines by means of SMS instant messages. At the same time and nation that an M-Commerce based managing an account administration was presented as well.

The first mobile commerce on the online was started in 1999 by a Japanese organization name was I-mode. IMode was permitted clients the capacity to peruse the net, 
read email, download entertainments and access other services. In the U.S.-limitless mobile phone arrangements have been none existent among significant carriers little a long time back, whereas, in the European markets, it has been the standard and now and again are the law. While Japan and Europe started $3 \mathrm{G}$ in 2001, the U.S. didn't introduce 3G until 2003 what's more, in Bangladesh 2012.

\section{B. M-Commerce in Bangladesh}

Before the end of 2008, the number of mobile subscribers was 44.6 million in Bangladesh from six operators. Where Grameenphone (47\%), Warid (5\%), Aktel (18\%), Banglalink (23\%), Citycell (4\%) and Teletalk (2\%) (BTRC, n.d).

Now, as of February 2016 the ratio becomes Grameenphone (43\%), Airtel (8\%), Robi (Atket) (21\%), Banglalink (24\%), Citycell (.064\%) and Teletalk (3.25\%) (BTRC, n.d).[11]

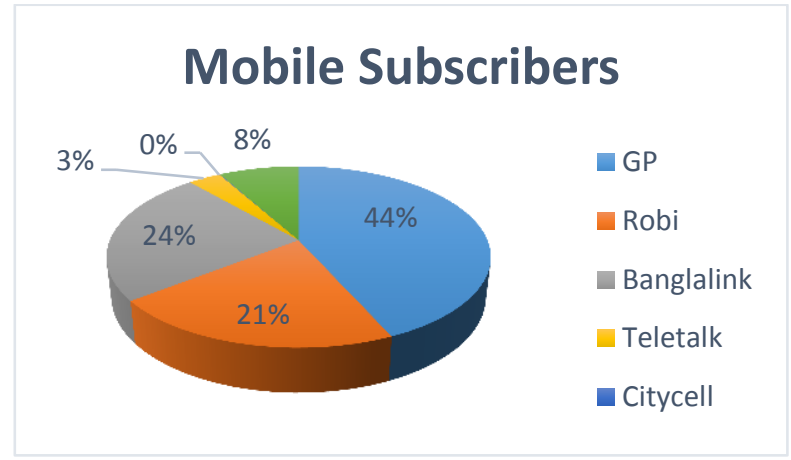

Fig.1. No of mobile phone subscribers as on February 2016

\section{PROSPECT OF M-COMMERCE}

\section{A. Increasing Number of Mobile Subscribers}

Currently, there are six mobile operators are providing mobile services to country peoples. At the end of June 2008, the number of subscribers was 43.7 million (BTRC, Annual Report, 2007-2008). Now it has reached to 133.05 million subscribers report at the end of February 2016[11] during the same period last year was 122.657 which means the number of subscribers increased by over 10 percent in one year.

The telecom base any nation influence the online benefits directly, cause it is to a great extent relied on upon it. The telecom selection rate expanded considerably in later years, which means more individuals are near the edge of utilizing e-business or take an interest as a part of e-trade exercises.

Comparative scenarios of mobile phone subscriber Till February 2016 [11]
Table 1. No of subscribers in Bangladesh

\begin{tabular}{|l|l|}
\hline Operator & No. of Subscribers \\
\hline Grameen Phone (GP) & 56.132 \\
\hline Banglalink & 31.960 \\
\hline Robi & 27.553 \\
\hline Airtel & 10.351 \\
\hline Citycell & 0.833 \\
\hline Teletalk & 4.257 \\
\hline Total & $\mathbf{1 3 1 . 0 8 5}$ \\
\hline
\end{tabular}

The data analysis has shown below using graph depending on the above number of subscribers of different mobile service providers.

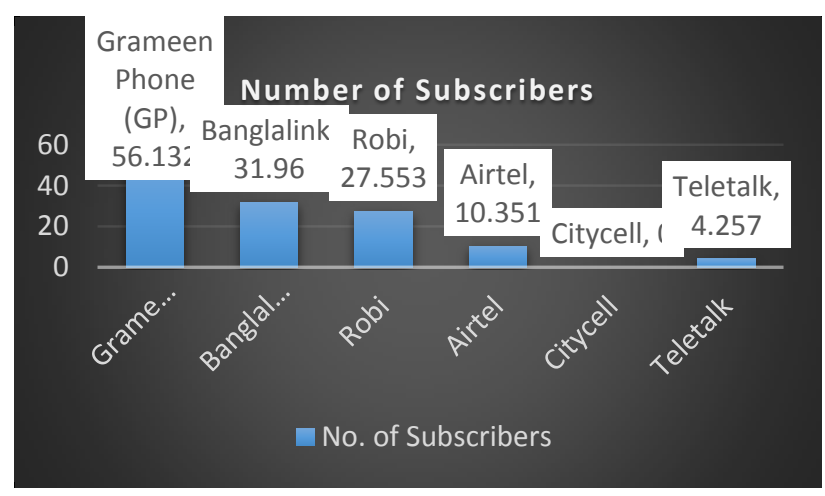

Fig.2. Comparative scenarios of mobile phone subscribers

\section{B. Increasing number of Internet users}

According to BTRC, the current mobile internet users has reached to 53.431 million at the end of January 2016 whereas ISP and PSTN internet users are 2.594 million. This expansion in web usage sets off the utilization of various e-business destination's past said in this task.

\section{TYPES OF M-COMMERCE SERVICES OFFERED IN BANGLADESH}

The central bank has given guidelines on "Mobile Financial Service for Bank" in September 2011. It has given 10 licenses to bank to perform full-fledged financial services using mobile. The two leaders have come forward with largest customer based and agent networks. The bKash was provided by BRAC bank and DBBL Mobile banking is provided by Dutch Bangla Mobile bank. Now mobile banking has become a very popular media to perform any financial activity. Now a day's mobile transactions has expanded to the following areas-

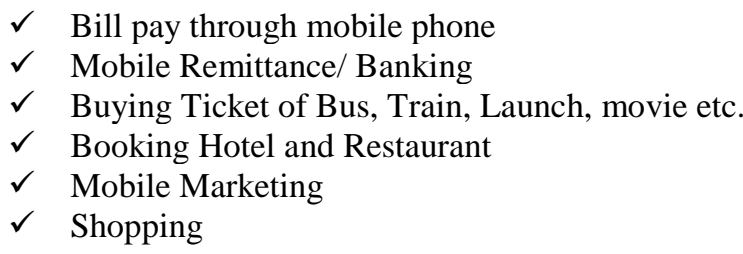




\section{THE PROBLEM OF THE RESEARCH}

In 1997 the internet was functioning for the first time in Bangladesh. (Debnath, 2007). At the starting point, the young population of the higher class used the internet for chatting and other web surfing. Internet was out of reach for poor people On the other hand around 32\% of total population use cellular telephones. So the risk of development of mobile commerce is more than that of ecommerce. However, the mass individuals can't get the benefits of most recent innovation of $\mathrm{M}$-commerce or electronic commerce.

The research proposed to do this examination to discover the suitable rule for installment framework for the association with the goal that it will convey many offices to mass individuals. Also, it is important to identify the constraint to implement m-commerce business in Bangladesh. As the mobile subscribers are increasing rapidly the government also should implement the new rules and regulations to expand m-commerce business. So that all customer shopping anywhere at any time without any hassle.

\section{CURRENT SCENARIOS OF M-COMMERCE IN BANGLADESH}

\section{A. Survey and Data Analysis among different providers}

There are a number of online businesses are found in Bangladesh those are doing M-Commerce. Most of the vendors are using the same policies for payment and other aspects. According to Alexa ranking few Bangladeshi sites are enumerated below-

Table 2. Subscribers site rank statistics

\begin{tabular}{|l|l|l|}
\hline Provider & Alexa Rank & BD Rank \\
\hline bikroy.com & 5,671 & 28 \\
\hline ekhanei.com & 17,136 & 98 \\
\hline kenakata.com & $9,800,265$ & no \\
\hline daraz.com.bd & 14,555 & 77 \\
\hline shoppersbd.com & 168,855 & 794 \\
\hline busbd.com.bd & 437,464 & 2,231 \\
\hline shohoz.com & 118,286 & 523 \\
\hline
\end{tabular}

According to the data's, a highest number of users are using Mobile commerce for buying tickets of different categories and second highest no of users are using mobile commerce for online shopping then third highest no of users are using $\mathrm{C} 2 \mathrm{C}$ for buying or selling products through online using mobile.

The graphical representation of site ranking using Alexa ranking is presented below-

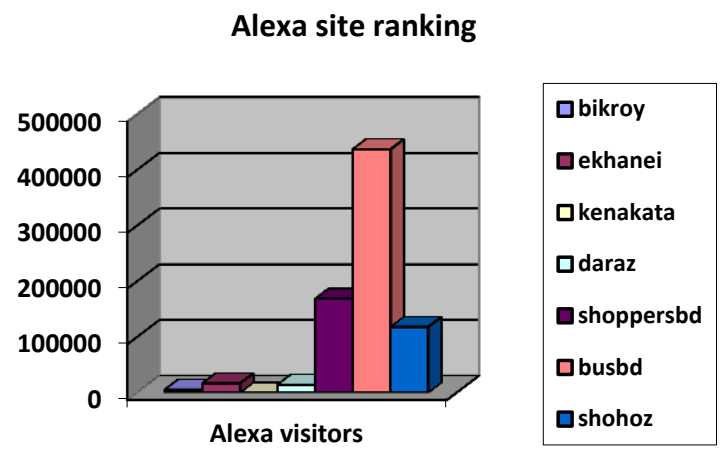

Fig.3. Alexa rank statistics

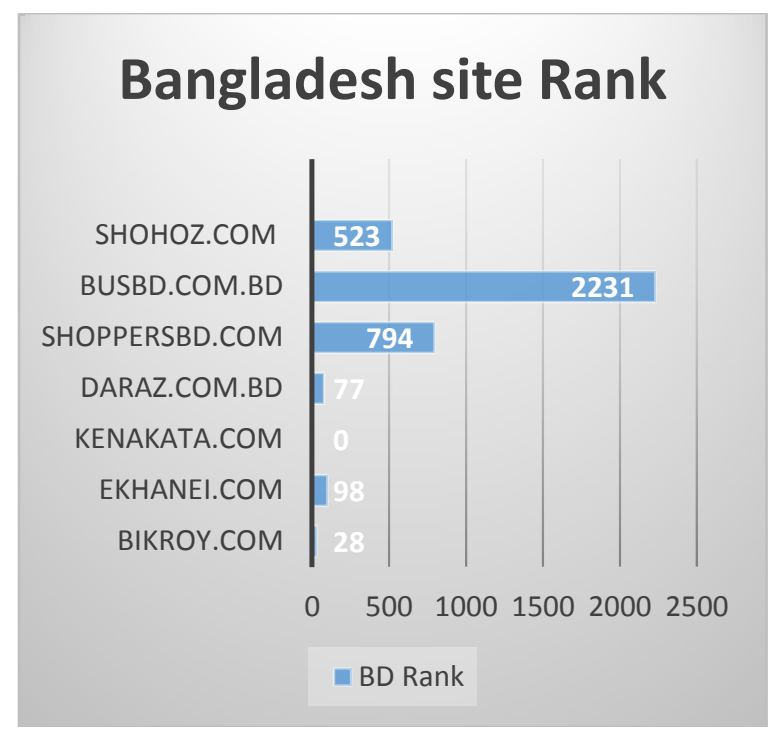

Fig.4. Bangladesh rank using Alexa

\section{RESEARCH METHODOLOGY}

Statistical data analysis depending on following criteria's are done for the bellow service providers. In these findings, most of the companies are using almost same payment system and policies.

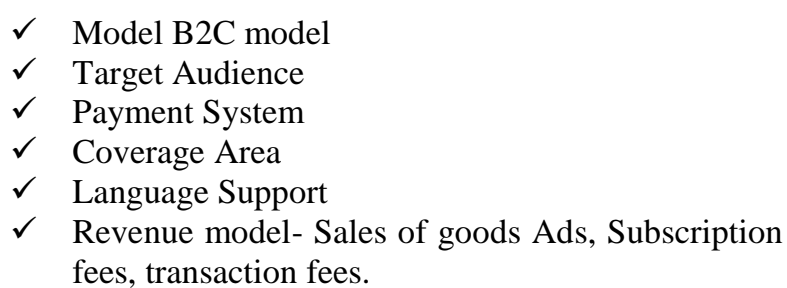

\section{DATA ANALYSIS}

A. ekhanei.com 
Table 3. ekhanei.com statistics

\begin{tabular}{|l|l|}
\hline Model & C2C model \\
\hline Target Audience & All Populations \\
\hline Coverage Area & Six Divisions \\
\hline Payment System & $\begin{array}{l}\text { Hand to Hand when } \\
\text { delivering the product. }\end{array}$ \\
\hline Site Access & No need to register. \\
\hline Language Support & English, Bengali \\
\hline Shipping Policy & Hand to Hand \\
\hline
\end{tabular}

\section{B. bikroy.com}

Table 4. bikroy.com statistics

\begin{tabular}{|l|l|}
\hline Model & C2C model \\
\hline Target Audience & All Populations \\
\hline Coverage Area & Six Divisions \\
\hline Payment System & $\begin{array}{l}\text { Hand to Hand when } \\
\text { delivering the product. }\end{array}$ \\
\hline Site Access & No need to register. \\
\hline Language Support & English, Bengali \\
\hline Shipping Policy & Hand to Hand \\
\hline
\end{tabular}

\section{C. daraz.com.bd}

Table 5. daraz.com.bd statistics

\begin{tabular}{|l|l|}
\hline Model & B2B, B2C, C2C model \\
\hline Target Audience & $\begin{array}{l}\text { Bangladesh, Pakistan, } \\
\text { Myanmar }\end{array}$ \\
\hline Coverage Area & $\begin{array}{l}\text { International provider } \\
\text { (Bangladesh, Pakistan, } \\
\text { Myanmar) }\end{array}$ \\
\hline Payment System & $\begin{array}{l}\text { Credit Card, bKash, Home } \\
\text { pay, Courier pay. }\end{array}$ \\
\hline Site Access & No need to register. \\
\hline Language Support & English, Bengali \\
\hline Shipping Policy & Hand to Hand, Courier \\
\hline
\end{tabular}

\section{D. shoppersbd.com}

Table 6. shoppersbd.com statistics

\begin{tabular}{|l|l|}
\hline Model & B2B, B2C model \\
\hline Target Audience & All Populations \\
\hline Coverage Area & Six Divisions \\
\hline Payment System & $\begin{array}{l}\text { Hand to Hand when } \\
\text { delivering the product. }\end{array}$ \\
\hline Site Access & No need to register. \\
\hline Language Support & English \\
\hline Shipping Policy & Hand to Hand, Courier. \\
\hline
\end{tabular}

E. chaldal.com

Table 7. chaldal.com statistics

\begin{tabular}{|l|l|}
\hline Model & B2B, B2C model \\
\hline Target Audience & All Populations \\
\hline Coverage Area & $\begin{array}{l}\text { Dhaka city, except certain parts } \\
\text { of Old town. }\end{array}$ \\
\hline Payment System & $\begin{array}{l}\text { Hand to Hand when delivering } \\
\text { the product, credit card bKash }\end{array}$ \\
\hline Site Access & Need to register. \\
\hline Language Support & English, Bengali. \\
\hline Shipping Policy & Hand to Hand, Courier. \\
\hline Products & $\begin{array}{l}\text { Food, Groceries, Home } \\
\text { appliances etc. }\end{array}$ \\
\hline
\end{tabular}

F. shohoz.com
Table 8. ekhanei.com statistics

\begin{tabular}{|l|l|}
\hline Model & B2C model \\
\hline Target Audience & All Populations \\
\hline Coverage Area & Whole Bangladesh \\
\hline Payment System & $\begin{array}{l}\text { Credit Card, Mobile bank } \\
\text { bKash and DBBL, SureCash, } \\
\text { MTB }\end{array}$ \\
\hline Site Access & Registration required \\
\hline Language Support & English \\
\hline Shipping Policy & Hand to Hand, Courier. \\
\hline Products & BUS, Train and Lunch, event \\
& and movie ticket \\
\hline
\end{tabular}

G. busbd.com.bd

Table 9. busbd.com statistics

\begin{tabular}{|l|l|}
\hline Model & B2C model \\
\hline Target Audience & All Populations \\
\hline Coverage Area & Whole Bangladesh \\
\hline Payment System & $\begin{array}{l}\text { Credit Card, Mobile bank } \\
\text { bKash and DBBL, SureCash. }\end{array}$ \\
\hline Site Access & Registration required \\
\hline Language Support & English \\
\hline Shipping Policy & Hand to Hand, Courier. \\
\hline Products & Bus ticket. \\
\hline
\end{tabular}

\section{MOBILE APPS STATISTICS OF M-COMMERCE PROVIDERS}

To explore M-commerce business, the first step is to develop mobile apps for the client for surfing and placing an order through mobile phone. Good mobile apps should be user-friendly, so that client can place an order without any hassle. For statistical analysis, I collected some data's from Google play store where few points are shown below in tabular format-

Table 10. Apps statistics from Google play store

\begin{tabular}{|l|l|}
\hline Providers & Google Play Data \\
\hline biroy.com & $\begin{array}{l}\text { Updated -April 1, 2016 } \\
\text { Size- 4.5M } \\
\text { Installs- 500,000 - 1,000,000 } \\
\text { Current Version- 0.9.57 } \\
\text { Requires Android- 4.0 and up } \\
\text { Content Rating- Rated for 3+ } \\
\text { Offered By- Bikroy }\end{array}$ \\
\hline ekhanei.com & $\begin{array}{l}\text { Updated- June 9, 2015 } \\
\text { Size- 5.5M } \\
\text { Installs- 500,000 - 1,000,000 } \\
\text { Current Version- 10.1.3.28 } \\
\text { Requires Android- 2.3.3 and up } \\
\text { Content Rating- Rated for 3+ } \\
\text { Interactive Elements } \\
\text { Users Interact, Shares Info }\end{array}$ \\
\hline $\begin{array}{l}\text { Updated- December 5, 2014 } \\
\text { Size- 4.5M } \\
\text { Installs- 10,000 - 50,000 } \\
\text { Current Version- 2.0 } \\
\text { Requires Android- 3.0 and up } \\
\text { Content Rating- Rated for 3+ } \\
\text { Offered By- Tech Fiesta }\end{array}$ \\
\hline
\end{tabular}




\begin{tabular}{|c|c|}
\hline daraz.com.bd & $\begin{array}{l}\text { Updated - March 23, } 2016 \\
\text { Size- } 8.0 \mathrm{M} \\
\text { Installs- } 1,000,000-5,000,000 \\
\text { Current Version- } 1.8 .1 \\
\text { Requires Android- } 4.0 .3 \text { and up } \\
\text { Content Rating- Rated for 3+ } \\
\text { Interactive Elements } \\
\text { Digital Purchases }\end{array}$ \\
\hline $\begin{array}{l}\text { bdonlineshop.c } \\
\text { om }\end{array}$ & $\begin{array}{l}\text { Updated- September 13, } 2015 \\
\text { Size- 13M } \\
\text { Installs- } 1,000 \text { - 5,000 } \\
\text { Current Version- } 3.0 .1 \\
\text { Requires Android- } 2.3 .3 \text { and up } \\
\text { Content Rating- Rated for 3+ } \\
\text { Offered By- NameLess }\end{array}$ \\
\hline $\begin{array}{l}\text { shoppersbd.co } \\
\text { m }\end{array}$ & $\begin{array}{l}\text { Updated- January } 8,2016 \\
\text { Size- } 2.6 \mathrm{M} \\
\text { Installs- } 1,000-5,000 \\
\text { Current Version-1.0 } \\
\text { Requires Android- } 2.3 \text { and up } \\
\text { Content Rating-Rated for 3+ } \\
\text { Offered By- DigiWebApps }\end{array}$ \\
\hline chaldal.com & $\begin{array}{l}\text { Updated- December 16, } 2015 \\
\text { Size- } 17 \mathrm{M} \\
\text { Installs- 5,000 - 10,000 } \\
\text { Current Version- } 1.1 .3 \\
\text { Requires Android- } 4.0 .3 \text { and up } \\
\text { Content Rating- Rated for 3+ } \\
\text { Offered By- Chaldal }\end{array}$ \\
\hline busbd.com.bd & $\begin{array}{l}\text { Updated- December 29, } 2015 \\
\text { Size- } 2.2 \mathrm{M} \\
\text { Installs- } 1,000-5,000 \\
\text { Current Version- } 1.2 \\
\text { Requires Android- } 4.0 \text { and up } \\
\text { Content Rating- Rated for 3+ } \\
\text { Offered By- MR Soft BD } \\
\end{array}$ \\
\hline Shohoz.com & $\begin{array}{l}\text { Updated- March 9, } 2016 \\
\text { Size - 6.0M } \\
\text { Installs- 1,000 - 5,000 } \\
\text { Current Version- } 2.2 .0 \\
\text { Requires Android- } 4.1 \text { and up } \\
\text { Content Rating- Rated for 3+ } \\
\text { Offered By- Shohoz.com }\end{array}$ \\
\hline bdtickets.com & $\begin{array}{l}\text { Updated- July } 24,2015 \\
\text { Size- } 4.7 \mathrm{M} \\
\text { Installs- 500 - } 1,000 \\
\text { Current Version- } 1.1 \\
\text { Requires Android- } 3.0 \text { and up } \\
\text { Content Rating- Rated for 3+ } \\
\text { Interactive Elements } \\
\text { Digital Purchases } \\
\text { Offered By- Boss Devs }\end{array}$ \\
\hline
\end{tabular}

According to downloaded and installed mobile apps of specific stakeholders, a statistical analysis has been done-

Table 11. Downloaded apps by users

\begin{tabular}{|l|l|}
\hline Provider & Installed mobile apps by No. Users \\
\hline bikroy.com & $500,000-1,000,000$ \\
\hline ekhanei.com & $500,000-1,000,000$ \\
\hline kenakata.com & $10,000-50,000$ \\
\hline daraz.com.bd & $1,000,000-5,000,000$ \\
\hline shoppersbd.com & $1,000-5,000$ \\
\hline chaldal.com & $10000-50000$ \\
\hline busbd.com.bd & $1,000-5,000$ \\
\hline Shohoz.com & $1,000-5,000$ \\
\hline
\end{tabular}

\section{Challenges AND OpPortunities}

There is no doubt that the main cause of the increase of mobile commerce is customer demand. The shopper like to have the flexibility and choose to shop online anytime at anywhere. Consumers are using more and more Smartphone and trying to compare the product and pricing from different online stores. At the same time, demand is creating for retailers to satisfy the customer by providing good services and building trust. The reality of the most customers of Bangladesh is that they would like to buy products by investigating on their own hand. Though there are a lot of M-commerce providers doing business around the country but still there are a lot of challenges are there those should be overcome to explore the possibility of this business. This research has found the bellow constraints or challenges -

- High internet uses cost

- Poor knowledge of internet promoting

- Absence of Government and Private companies' involvement

- Lack of ICT education and Training

- Poor literary knowledge

- Absence of shipping policy

- Lack of Privacy policy

- Restriction of online payment gateway

- Achieving of Client trust

- Lack of awareness

\section{CONCLUSION}

This research has examined some important factors of M-Commerce those were not written earlier like the current growth of mobile and mobile internet users in Bangladesh, research also has been done on m-commerce providers site rank using tools and statistics of mobile apps uses by customers. M-commerce business scenarios and limitations those includes an absence of secure payment systems, lack of awareness, lake of achieving client trust and poor ICT knowledge.

\section{LIMITATION AND FUTURE RESEARCH}

This research is neither a technical research of mcommerce nor does it discuss the government policies, rather finding out the opportunities and challenges of $\mathrm{m}$ commerce in Bangladesh based on the experimental study. It would be better if I could collect data using questionnaires to survey that could have helped address the specific issue that emerged later in the study.

Future exploration could quantify the financial effect of m-commerce. Investigation of Governmental strategies in this field could be a decent research work. The other significant examination could be to perceive the total amount of revenue generated from mobile commerce. 


\section{REFERENCES}

[1] Md. Aminul Islam, Tunku Salha Binti Ahmad, Mohammad Aktaruzzaman Khan \& Mohammad Hasmat Ali, Adoption Of M-Commerce Services: The Case Of Bangladesh, World Journal of Management, Vol.2 No.1 March 2010, Pp. 37-54

[2] Ohidujjaman, Mahmudul Hasan and Mohammad Nurul Huda, "E-commerce Challenges, Solutions and Effectiveness Perspective Bangladesh " in International Journal of Computer Applications (0975 - 8887), Volume 70- No.9, May 2013

[3] Mohammed Mizanur Rahman, "Barriers to M-commerce Adoption in Developing Countries - A Qualitative Study among the Stakeholders of Bangladesh", The International Technology Management Review, Vol. 3 (2013), No. 2, 80-91

[4] The web information company: http://www.alexa.com/siteinfo/clickbd.com

[5] Online shopping, selling or buying: http://www.bikroy.com/

[6] Online shopping, selling or buying: http://www. khanei.com

[7] Online shopping, selling or buying : daraz.com.bd

[8] Online shopping, selling or buying : shoppersbd.com

[9] Online bus reservation service : busbd.com.bd

[10] Online bus, train and hotel reservation service: Shohoz.com

[11] Advance financial inclusion to improve the lives of the poor. Available at- http://www.cgap.org/blog/growthmobile-financial-services-bangladesh

[12] Bangladesh Telephone Regulatory Commission [BTRC], Accessed on $1^{\text {st }} \quad$ April 2016 . http://www.btrc.gov.bd/content/mobile-phone-subscribersbangladesh-february-2016

[13] A. Smith, Exploring m-commerce in terms of viability growth and challenges. International Journal of Mobile Communication, 4(6) (2006) pp.682-703

[14] Zhang, J. (2009). Exploring Drivers in the Adoption of Mobile Commerce in China. Journal of American Academy of Business, 15, 64-69.

[15] Swilley, E. (2007). An Empirical Examination of the Intent of Firms to Adopt Mobile Commerce as a Marketing Strategy [dissertation]. Florida (US). Florida State University

[16] Abdel Nasser H. Zaied, Barriers to E-Commerce Adoption in Egyptian SME, I.J. Information Engineering and Electronic Business, 2012, 3, 9-18

\section{Authors' Profiles}

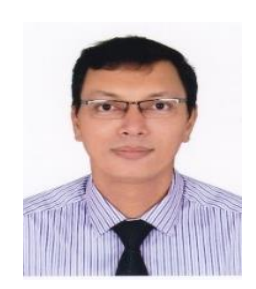

Biman Barua received his B.Sc. in Computer Science in the year of 1999 from University of Madras, INDIA and M.Sc. in Communication Engineering, M.Sc. in Computer Science and Engineering respectively.

He has been working as Senior Lecturer at BGMEA University of Fashion and Technology (BUFT), Bangladesh from 2008 prior to that he also worked in various multinational organizations as IT Manager. His areas of teaching are Electronic commerce, EBusiness, e-Professional etc.

How to cite this paper: Biman Barua,"M-Commerce in Bangladesh -Status, Potential and Constraints", International Journal of Information Engineering and Electronic Business(IJIEEB), Vol.8, No.6, pp.22-27, 2016. DOI: 10.5815/ijieeb.2016.06.03 